\title{
PENNY UR'S 100 TEACHING TIPS (BOOK REVIEW)
}

\section{Shpilchak Liubov ${ }^{1}$}

\author{
DOI: https://doi.org/10.30525/978-9934-571-89-3_36
}

The aim of the review is to give a concise and critical overview of the book by Penny Ur. This is a Cambridge handbook for language teachers edited by Scott Thornbury and first published in 2016 by Cambridge University Press. The book provides a set of 100 hands-on tips on 19 different areas of classroom teaching, including using a course book, giving and checking homework, classroom discipline, testing and assessment. Brief explanatory notes are based on the author's extensive teaching experience. Penny Ur started teaching in Israel in 1968. She has taught English in elementary, middle and high schools for over 40 years. She has also led courses on MA programs, presented at conferences around the world and authored a number of books.

The author has covered all aspects of language teaching in a balanced fashion. The book has a clear structure; it is logically divided into different aspects of teaching. Therefore, the reader may not read the whole book, but rather browse through it looking for headings of specific interest. The topics are listed alphabetically, each followed by a set of associated tips. Each tip appears at the top of the page, followed by comments, which include examples of classroom procedures, references to research or Internet sources.

The author is aware of the fact that the readers may find they need to modify or adapt some of the tips, or even completely reject them. She considers her tips not to be "directives from an authority" but rather "suggestions from a colleague". One must use them selectively and critically.

The author is effective and persuasive in sharing her own professional experience understanding that ours may be quite different as well as one's teaching personality, the character and expectations of our students.

The main argument of the book is that teaching a foreign language is an interesting and easy process in case it is well planned and properly organized taking into consideration the learners' needs. The author intended to demonstrate the ways to

\footnotetext{
${ }^{1}$ Ivano-Frankivsk National Medical University, Ukraine
} 
perform different lesson components, like beginning and ending the lesson, homework, testing and assessment, etc. She draws the readers' attention to such basic and at the same time trivial things as error correction, grammar explanation, fluency in speaking and eye contact. For example, the author suggests that the teacher should correct (sometimes) during speech, though some other teachers advise not to interrupt students; for grammar explanation students' mother tongue can be used. The recommendation to avoid grammatical terminology might be interesting as well. Besides, if students know a few samples of the use of a grammatical structure by heart, they can often create more of their own, intuitively feeling what is "right" [1, p. 35].

Dividing students into groups or pairs immediately multiplies the amount of time each student has to practice speaking. A class of 20 divided into five groups of four gives each student five times as many opportunities to speak, as he or she would have had in a full-class interaction [1, p. 87]. One of the things that stop students from participating in a speaking activity is that they simply do not have enough English to be able to say what they need to. Therefore, the task needs to be designed to use mainly language they already know [1, p. 90].

What I find most impressive about the book is the idea about lots of teacher talk in class. The author considers it an excellent source of English language comprehensible input. Therefore, contrary to some opinions about learner-centered classroom, Penny Ur supports the idea of teacher-centered classroom. "Be aware that you are on show, and use facial expressions, gesture and movement to make what you are saying more interesting" [1, p. 65]. Some of the author's conclusions might conflict with other books or courses but she uses enough convincing evidence based on her own teaching long-lasting experience to prove her point of view. The author also supports her arguments with vivid examples from her classroom teaching. Besides, she gives some good advice: "Do your own thing!" To be good at teaching you need to find your own teaching style and choose the methodology that suits you and your students [1, p. 118]. And one more thing to remember: Time and work invested in making the lesson interesting is well worth the effort $[1$, p. 59].

Some more fresh ideas are as follows: to use the course book critically and selectively, not just follow page by page; not to give homework at the end but explain it sometime in the middle of the lesson and make sure students have noted it down. The teacher's task is to make homework success-oriented and provide feedback on it. The importance of using group work has been rather over-rated in the professional literature. Pair work gets better results than group work: it is easier to set up and control, and ensures more participation [1, p. 41].

Concerning the basic language skills, the author's idea is that "listening is probably the most important of the four skills: it is the starting point for learning any language. Therefore, just asking students to listen and understand is a bad idea". At the same time, pronunciation is probably the aspect that needs least teaching [1, p. 66- 67].

I find particularly useful Tip 68: "Reading aloud in English is not in itself a very useful skill for most students' future lives. So, don't make students read aloud, as 
his/her attention is necessarily on pronunciation and phrasing, not on comprehension (the exception is early stage of learning)" [1, p. 81].

"Penny Ur's 100 Teaching Tips" greatly enhances the understanding of the teaching issues at hand. It gives new teachers a great chance not to "re-invent the wheel" or discover a useful teaching idea much too late, but shorten the process of learning from their predecessors. The book's particular originality allows us to see what specific contribution it makes to understanding teaching as a complicated process.

It contains tips really worth using in language teaching. I advise everyone to use some of these tips in his/her language teaching. Anyone who is interested in professional self-development will really enjoy reading "Penny Ur's 100 Teaching Tips". Obviously, the reasons for the overall positive review are plainly visible and readers might benefit from this book. I suggest the audience would appreciate it. I would highly recommend this book to a potential audience as one could find enough interesting and useful teaching ideas to make his/her reading worthwhile.

\section{References:}

1. Penny Ur. Penny Ur's 100 Teaching Tips. Cambridge University Press, University Printing House, Cambridge CB2 8 BS, United Kingdom, 2016. - 120 p. 